\title{
The discovery of lymphatic system as a turning point in medical knowledge: Aselli, Pecquet and the end of hepatocentrism
}

\section{Tonetti ${ }^{1}$}

${ }^{1}$ Department of Philosophy, Sapienza University of Rome, Italy

presented to: the Hemodyn2015, Nov 2015, Naples, Italy submitted: Jun 24, 2017, accepted: Sep 16, 2017, EPub Ahead of Print: Dec 22, 2017, published: Dec 31, 2017

Conflict of interest: None

DOI: 10.24019/jtavr.27 - Corresponding author: Dr. Luca Tonetti, tonetti.luca@gmail.com

(C) 2017 Fondazione Vasculab impresa sociale ONLUS. All rights reserved.

\begin{abstract}
In this paper, I would like to analyse the impact of the discovery of lymphatic system on the development of the modern conception of human body. The discovery of lymphatics, as that of blood circulation, has in fact questioned important tenets of Galen's anatomophysiology. Galen defended a 'dualistic conception' of the blood: he distinguished two different systems, the hepatic-venous system and the cardio-arterial one. The liver played a pivotal role because it was believed to transform the chyle received by the portal vein into venous blood. The discovery of lymphatics challenged this view: $17^{\text {th }}$ century anatomical dissections and experiments, starting with the discovery of milky veins by Gaspare Aselli (1581-1625) and the studies on thoracic duct by Jean Pecquet (1622-1674), irrefutably showed that the chyle does not pour out in the liver and that, consequently, the liver does not produce blood.
\end{abstract}

Keywords lymphatic system, chyliferous vessels, hepatocentrism, Gaspare Aselli, Jean Pecquet

\section{Introduction}

The history of the lymphatic system has recently caught the attention of both historians of medicine and physicians (phlebologists, lymphologists, haematologists, and so on), particularly those interested in the historical, methodological and ethical issues related to their discipline. Over the years, numerous scholarly medical journals among others, Lymphology, Clinical Anatomy, British
Journal of Haematology, Acta Chirurgica Belgica, or in Italy Acta Phlebologica - have devoted much space to history, through short historical reviews or dedicated sections. $^{1-4}$

It is also worth mentioning that in 2015, the Academy of Fisiocritici, a learned society founded at Siena in 1691 and still active today, celebrated the bicentenary of the death of his past president Paolo Mascagni (1755-1815), one of the leading representatives of the eighteenth-century anatomy in Italy and, in particular, of the history of lymphatic system. ${ }^{5-7}$ In 1787, Mascagni published a large folio volume, Vasorum lymphaticorum corporis humani historia et ichnographia ${ }^{8}$, in which he described and represented for the first time, in 41 plates, the entire structure of human lymphatics by means of mercury injection. ${ }^{[i],} 9$ Mascagni's research on lymphatics was started in 1777 with experiments on bodies affected by extreme generalised oedema or dropsy: indeed, this particular diseased state, consisting of a massive swelling of the body, allowed him to quickly locate vascular vessels and, therefore, to trace the minutest ramifications of lymphatics throughout the body thanks to mercury injection. In 1784, the French Académie des sciences devoted a special competition on this topic, which, albeit quickly discontinued for lack of contributions, offered Mascagni the opportunity to outline a first explorative description of his anatomical experiences in a volume, Prodrome d'un ouvrage sur le système des vaisseaux 
lymphatiques (1784) that is the basis for his further work. ${ }^{[i i],}$ 10

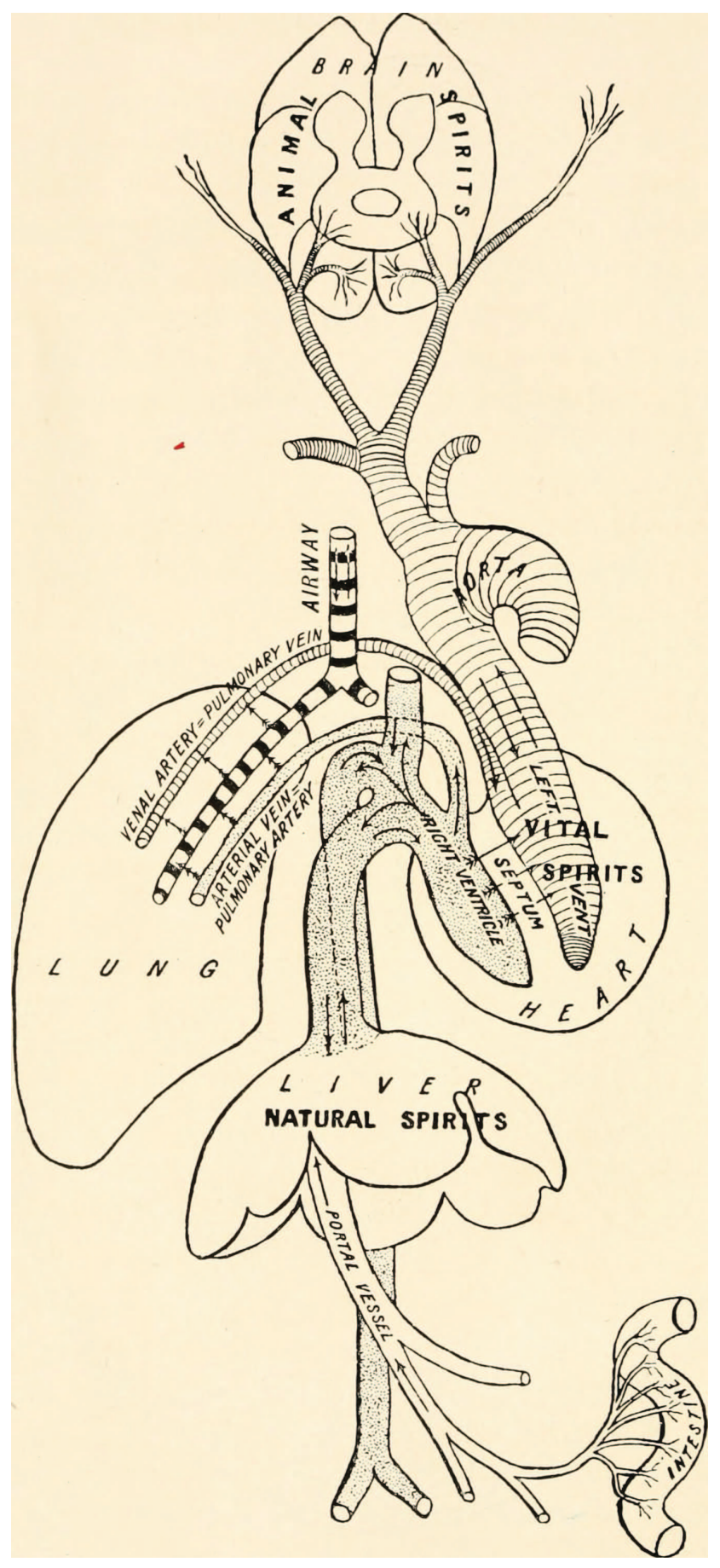

Figure 1 - Galen's vascular system. From Singer (1922, plate II).

The prolegomena to Historia et ichnographia shows Mascagni's accurate knowledge of the $16^{\text {th }}$ and $17^{\text {th }}$-century secondary literature on lymphatics, as we can see in the most of the books that he personally owned, and that are now preserved in the library of the Academy in Siena ${ }^{[i i i]}$.

While recognising the pivotal role of Aselli's discovery of "milky veins," Mascagni himself highlighted the main consequence of Pecquet's work against Aselli's interpretation of lymphatics: disproving the haematopoietic function of the liver.

In this short paper, I will deal with exactly this issue, in order to understand how the early modern studies on lymphatics have considerably changed our conception of the human body. In particular, I will first describe the traditional view on this topic, which was influenced by Galen's conception of blood physiology; then, I will focus on two leading figures of the history of lymphatics: Gaspare Aselli and Jean Pecquet. I will analyse some scientific implications of their works for the modern conception of human body, the main of which is the refutation of hepatocentrism.

\section{Liver's role in Galen's physiology and its legacy}

Galen's vascular system distinguishes two different and separated paths of blood throughout the human body. In the first one, the blood, once produced by the liver, moves through the veins and reaches the upper and lower parts of the body, in order to feed them. In the second one, a part of the venous blood reaches the right ventricle of the heart by the vena cava inferior, then, passes to the left ventricle thanks to the meatuses of the interventricular septum allowing only the thinner parts of it to pass through. There, the blood, mixed with the pneuma coming from the lungs, is elaborated and pumped in the aorta, and finally reaches the other parts of the body through the arteries (see Fig. 1) ${ }^{11}$.

This organisation of blood physiology implies that (1) Galenic vascular system is mainly "open-ended", because these two sub-systems, hepatic-venous and cardio-arterial, do not communicate, but they are completely independent of each other. Since it does not circulate, the blood cannot be recycled and is believed to be consumed throughout the body. Moreover, this organisation implies also that (2) there are two different kinds of blood: the blood flowing in the hepatic-venous sub-system is thick and raw because of the nutrients filled in, and it has a nutritive function. On the other hand, the blood flowing in the cardio-arterial subsystem is "vitalised" and it is aimed at bringing the pneuma throughout the body. Overall, according to Galen the liver plays a pivotal role in blood physiology, because it is the main source of the veins and it represents the body part, in which the process of haematopoiesis takes place.

In other words, the liver produces blood - in particular, venous blood - by transforming the chyle 
received by the portal vein, just like a bakery that bakes and makes fit for nourishment the wheat collected in the storehouse. In Galen's analogy, the bakery is the liver, the wheat is the nutriment elaborated in the stomach, and the porters are the veins responsible for carrying the blood to the liver. ${ }^{12}$

Following the same analogy, Galen writes:

When the liver has received the nutriment already prepared by its servants and having the crude outline, as it were, and indistinct semblance of blood, it provides the final elaboration itself so that the nutriment becomes actual blood. The impurities corresponding to the earth, stones, and seeds of wild plants in the wheat were eliminated from the food in the stomach, but this stands in need of a second cleansing from the impurities corresponding to the chaff and bran in wheat, and it is the liver which accomplishes this further purification of the nutriment (Ibidem, p. 205).

Thus, the liver represents the place for the second concoction that follows the first, preparatory elaboration happening in the stomach. However, how does this process occur? In De usu partium IV, Galen tries to identify which part of the liver is responsible for the origin of the veins and for the blood formation, and concludes that the only part to be considered is the flesh of the liver, i.e. its substance (Ibidem, p. 222). The process involved is that of assimilation: the nutriment is gradually reduced to the same substance of which the liver itself is composed - that is blood - by means of a complex network of veins that retains it long enough to be transformed:

If a single, large cavity had been formed in the liver, the blood would not tarry there and only a very small portion of it would come in contact with the flesh of the viscus, with the result that sanguification would be impaired; for if the characteristic substance of the liver is the principal instrument of sanguification, nutriment that is more closely associated with this substance will take on the nature of blood more quickly and thoroughly (Ibidem, p. 226-7)

Finally, it is worth thinking about the fact that, for Galen, the flesh of the liver is the "main," but not the only part of the body responsible for the sanguification: in fact, it is supposed that also veins - precisely to the extent that they originate from the liver - could perform some mild form of haematopoiesis. This means that the meseraic veins carrying the chyle to the liver already make a change of some sort on the nutriment: interestingly, this specific point will be debated and refuted by Renaissance anatomists.

In fact, by arguing in favor of direct observation on human bodies (and not on animals), early modern anatomists reversed the relationship between authority and experience. As a result, the inaccuracies of Galen's view emerged and some of the main principles of his anatomy and physiology — such as the absence of pulmonary transit or the impermeability of the septum - were questioned. However, despite the evidence of Galen's errors, the centrality of the liver persisted. This is, even so, clearly exemplified by the way in which the study of human anatomy was still organized at that time: that is, according to the order imposed by Galen in De anatomicis administrationibus (osteology $>$ muscles $>$ arteries and veins $>$ nerves $>$ organs), paying particular attention to those who were considered the three main parts of the body - the liver, the heart, and the brain. Within a Galenic framework, the liver can only be considered the source of the venous system and the bodily part responsible for blood production.

This is the case of Vesalius who, despite having detected numerous mistakes in Galen, thus marking the birth of modern anatomy, failed to propose a valuable alternative to Galen's conception of the body ${ }^{[i v], ~ 13, ~}$ 14. In the Tabulae anatomicae sex $(1538)^{15}$, his first anatomical contribution consisting of six different plates, he represented the vascular system according to the "old" anatomy, in accordance with Galen's authority. ${ }^{16}$ Fig. 2 shows the plate I, which represents a five-lobed liver serving as "officina sanguificationis" with the entire ramification of the portal vein: in this way, the chyle is carried from the stomach and the intestines to the liver, and the waste product (the "succum melancholicum") excreted in the spleen. There is no difference with what was taught by Galen.

Plate II (Fig. 3) is instead devoted completely to the description of vena cava, by which blood can reach all the parts of the body and feed them ("qua sanguis omnium partium nutrimentum per universum corpum diffunditur").

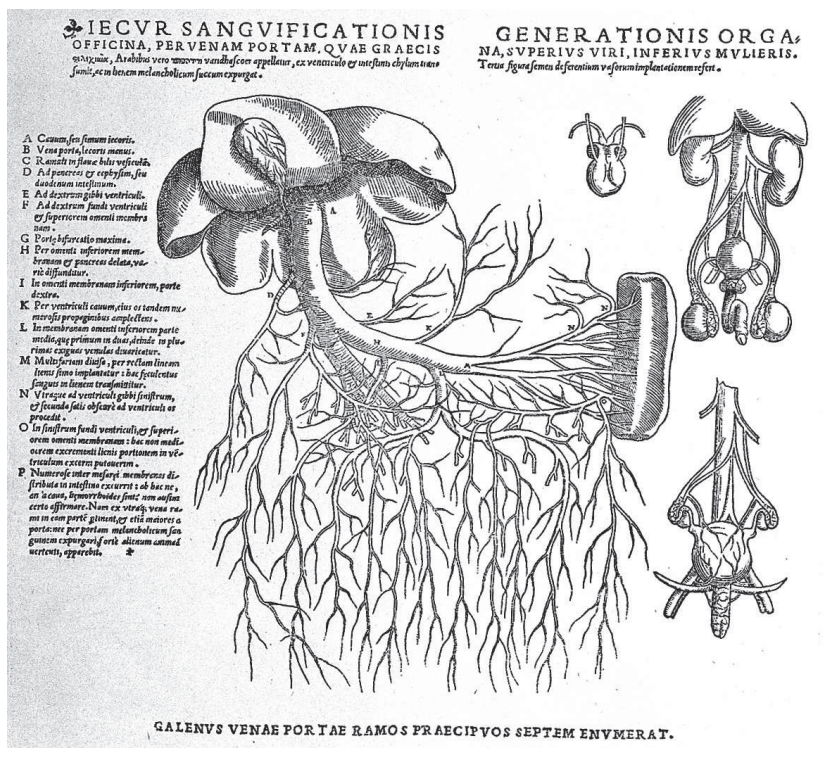

Figure 2 - Plate I: Description of the liver, the portal system and the organs of generation (male/female). From: Tabulae Anatomicae sex (1538) ${ }^{15}$. 


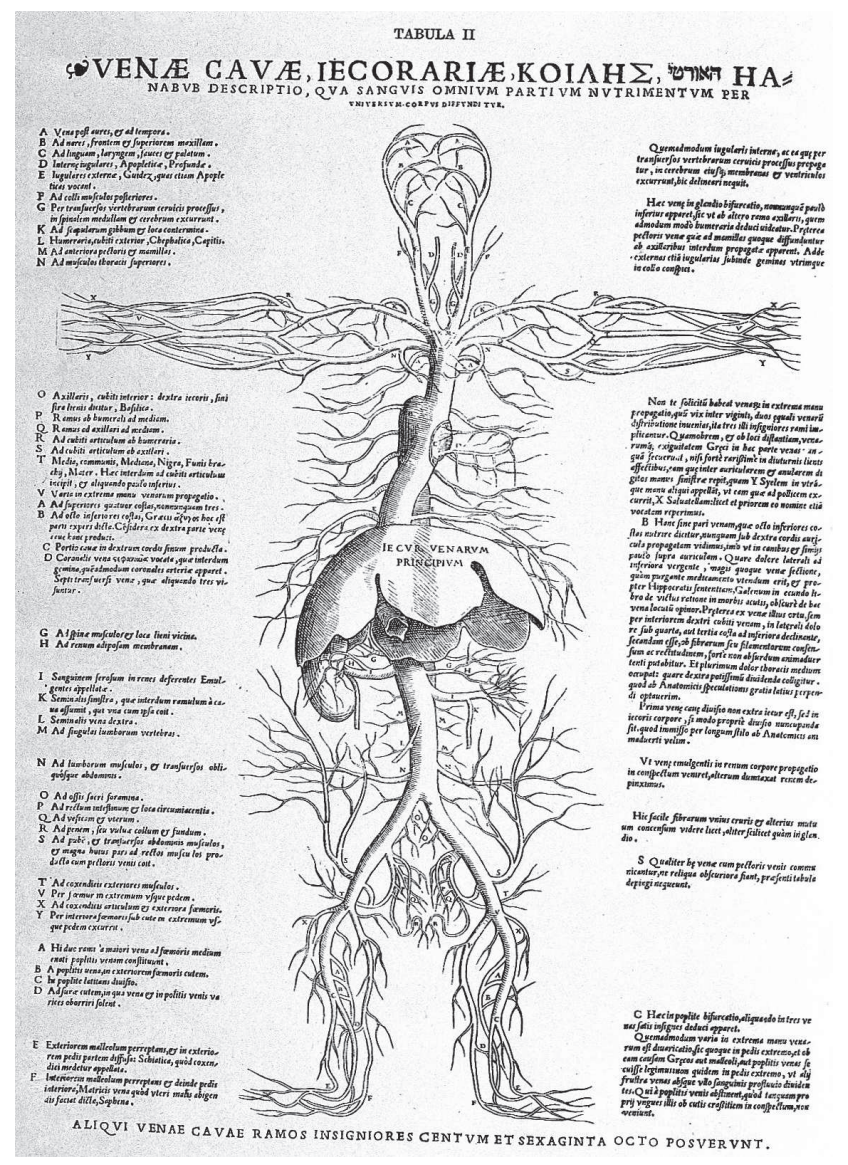

Figure 3 - Plate II: Description of the caval system. Liver is labelled: "Iecur venarum principium" (Liver source of the veins) (Vesalius 1538, Plate II).

At that time, Vesalius still believed - in respect (again) of Galen's authority — that the entire venous system had originated from the liver (here labelled as "iecur venarum principium"), including caval system, which is depicted as a continuous vessel.

Vesalius revised this position in his masterpiece De humani corporis fabrica $(1543)^{[\mathrm{v}], 17,18}$. First of all, he rejects that representation of the liver in five lobes that he probably borrowed from medieval anatomists. Nevertheless, this idea implicitly recurs in the fact that, anyway, the portal vein entering the liver is supposed to be branched in (again) five different vessels (see the top of fig. 4) (Singer 1946, p. lviii-lix)

Secondly, contrary to what previously believed, he abandons the argument advanced by Galen about the origin of the caval system and rather maintains that the vena cava arises directly from the heart, without necessarily denying the flow of blood from the liver, or at least from the offshoots of the portal vein.

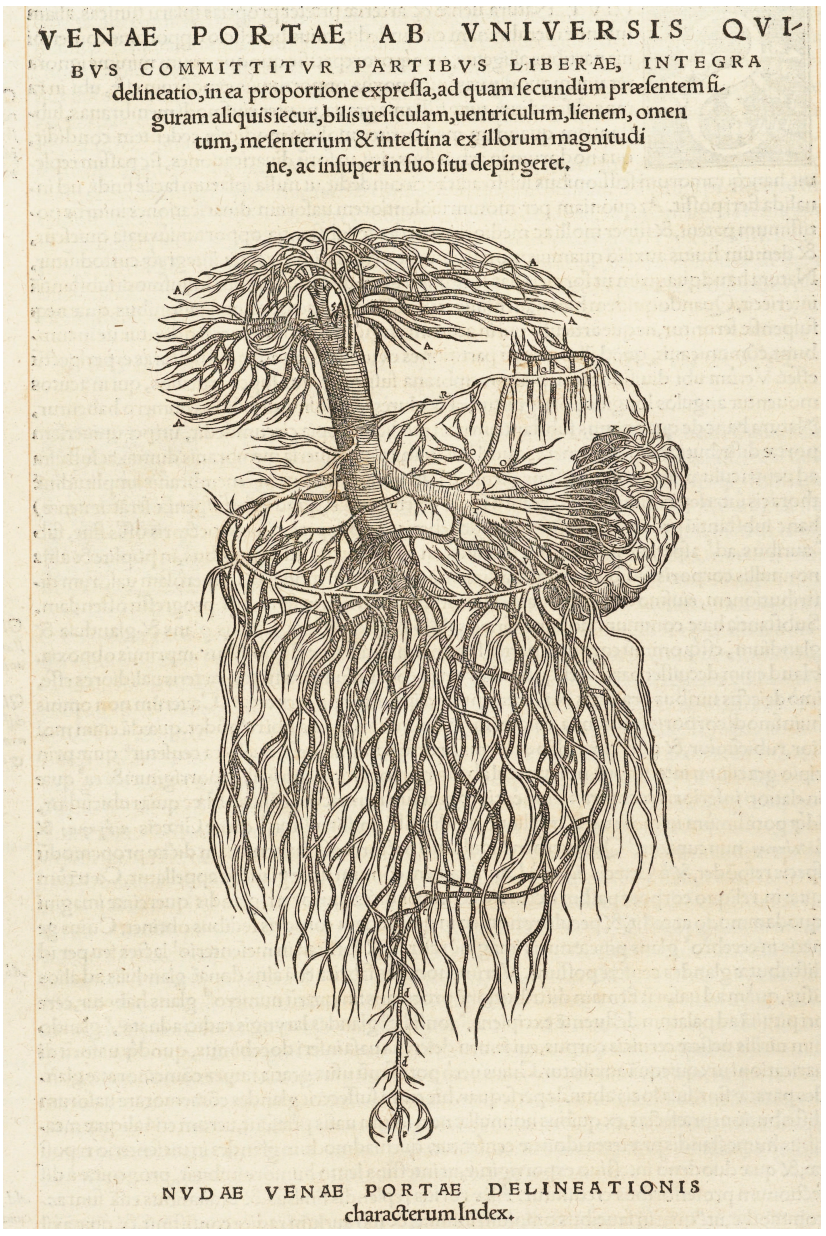

Figure 4 - Description of the portal system. From Vesalius (1543).

Finally, he revises the process of bloodmaking: although still attributing it to the liver, Vesalius does not recognise a form of haematopoiesis, albeit weak, to the portal veins:

The most and juicy product of the processing carried out by the stomach is gathered in from the intestines and from the stomach itself by the branches of the portal vein and conveyed to the liver. I would not agree that these branches, before conveying the juice or pulp to the liver, make it into a crude form of blood and so, as Galen claims, prepare it in exactly the same way as the liver does; for if the veins (and not only these ones but all offshoots of the hollow vein) had, in addition to the power of transforming their own proper nutriment, a power of transformation like that in the stomach serving the body as a whole, they would change the contents of the veins, not into something red, but into something white: the rule is that in nutrition the thing transformed takes the color of the thing transforming. The liver takes into itself and into all the branches of the portal vein that spread through its substance all the moisture and juice processed by the stomach and, by virtue of the transforming power innate in its own substance, makes it resemble itself as closely as possible, thus generating blood. ${ }^{19}$

Liver's pivotal role is supported also by Realdo Colombo in his main work De re anatomica (1559), published a few 
years later the second edition of Fabrica $(1555)^{20-21}$ : aside from denouncing the errors of Galen, Colombo critically reflects also on the work of Vesalius. On the one hand, in accordance with Galen, he claims that the liver is the "omnium venarum caput, fons, origo et radix,"(Colombo 1559 , p. 164) whose task is making blood. Thus, as a vein, the portal vein arises from the concave part of the liver. Then, its main trunk is divided in seven branches. The first two of them - which we can compare with what today we call the left and right gastric veins - reach the upper and lower part of the stomach, respectively. They both have the task of feeding the stomach. The third branch reaches the omentum. The fourth, as a sort of splenic vein, conveys the black bile humour to the spleen. The last three branches, the fifth, the sixth, and seventh, all serve the intestine, but at different points: correspondingly, the colon, the small intestine, and the rectum (Ibidem, p. 164-165). At this point, Colombo makes a very often neglected remark: he claims that the innumerable and extremely small veins in which are divided the branches reaching the intestine, i.e. the meseraic veins, have valves at their ends. Just as what happens in ureters, valves prevent the chyle from turning back. In other words, they give it a specific direction, from the intestine to the liver, which is in charge of transforming it into blood. In this way, accidentally, Colombo not only identifies the chyliferous vessels (meseraic veins), but, by highlighting the existence of valves inside them, he somehow anticipates the idea of a flow of chyle, that anyway cannot be defined circulation yet (Ibidem, p. 165; Colombo 2014, p. 456, n 12). On the other hand, contrary to what claimed by Galen in De usu partium IV, Colombo, just like Vesalius, denies to the portal vein and its ramifications a power of sort of transforming the chyle into blood.

Unfortunately, the lack of anatomical plates has severely limited the dissemination of Colombo's work compared with that of Vesalius, although Colombo's attacks on Galen's physiology are more explicit. Colombo, for example, strongly denied the existence of the meatuses of the interventricular septum, arguing that the passage of blood from the right ventricle to the left one was possible only by assuming the existence of a pulmonary transit (Colombo 1555, p. 177).

\section{From Aselli to Pecquet: A challenge to Galen's physiology}

The most common $17^{\text {th }}$-century anatomical treatises continue to emphasize the pivotal role of the liver. It is thus hardly surprising that Aselli too had worked in a Galenic framework. Gaspare Aselli (1580-1625) was professor of anatomy at the University of Pavia in 1624-25 22 (Fig. 5) ${ }^{23}$. His main work De lactibus sive lacteis venis, based on his four lectures on lacteals held in 1625, was published posthumously in 1627 by his friends and colleagues Alessandro Tadino and Senatore Settala, only one year before the publication of William Harvey's work on blood circulation (De motu cordis) ${ }^{[\mathrm{vi}], 24}$. This book consists of thirty-five short chapters, provided with four folio-size chiaroscuro woodcuts of canine lacteal vessels, that probably represent the first colour-printed anatomical illustrations ${ }^{25}$.

Aselli aims here to show the existence of a new kind of vessels, the chyliferous vessels, which he names "milky veins". The discovery of what seems to be a fourth vessel (the other three being the arteries, the veins, and the nerves) is the result of a dissection on dog occurred in 1622. At the bottom of the beautiful title page engraved by Cesare Bassano, there is a clear reference to the chyliferous vessels and their insertion in the liver, which is the main topic of the work (see Fig. 6).

It is firstly worth noting that Aselli's work follows Fabricius' format for anatomical reports, that consists of a three-section structure: historia, actio, utilitas. Anatomists should firstly provide a full description of the concerned body part, without any tentatively reference to causes. This means that the first section, called "historia," focuses only on the structure of the part. Secondly, anatomists should proceed with "actio," that is the description of the action of the part. Finally, the last section, "utilitas," should offer the account of the final causes, that is, the reasons why that part exists $^{\text {[vii], 26-28. }}$.

In the section devoted to historia, after describing the main mesenteric vessels, Aselli provides a detailed report of his accidental discovery ("De Quarto, \& novo Vasorum Mesairacorum genere"). On July 23, 1622, Aselli dissected a post-prandial dog, in order to see the recurrent nerves and the movements of the diaphragm. However, the opening of the abdomen and the displacement of the intestines suddenly revealed something completely new, that is "a great number of slender cords, so to speak, extremely thin and white, scattered all over the whole mesentery and intestine, from almost innumerable starting points" [viii], 29. Aselli believed those "cords" to be nerves, but then he realized that this hypothesis was untenable. Influenced by the scholarly disputes on meseraic veins, he decided to lance one of those whitish filaments so as to look at it inside. He noticed a milky liquid filling in, a feature that suggested him the name of "venae albae et lactae." Then, in support of his discovery, he dissected another dog, but without finding the new vessels. But, since this second dog was unfed, he inferred that there was a correspondence between the food intake and the chance to detect the chyliferous vessels. Thus, he tried again with a third dog, but after six hours from the animal's last meal. Indeed, the vessels reappeared. 


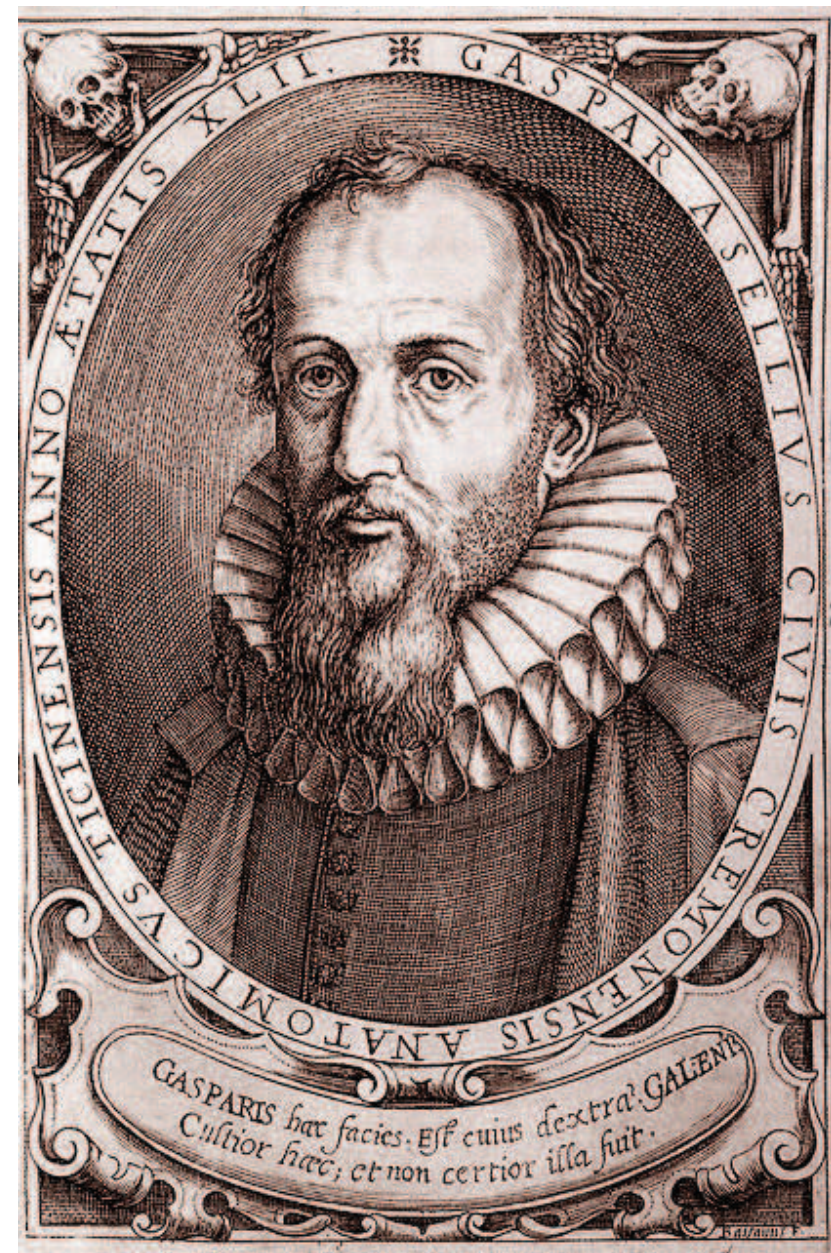

Figure 5 - Gaspare Aselli's portrait, by Cesare Bassano.

Nevertheless, despite the novelty of his discovery, Aselli continues to support Galen's physiology: as a consequence, chyliferous vessels are considered to lead to the liver, which inevitably preserves its privileged position as the organ of sanguification. "Le mensonge se mêle ici à la verité" ${ }^{30}$, as Portal wrote in his Histoire de l'anatomie et de la chirurgie. In particular, by describing the progressus of chyliferous vessels, Aselli confused a large mesenteric lymphatic gland with a pancreas of sorts (now known as Aselli's pancreas or Aselli's gland), from which larger vessels were supposed to reach the caval vein, the portal vein, or directly the liver (Ibidem). In Fig. 7, all milky veins scattered in the mesentery (marked by the letter B) converge in Aselli's pancreas (letter L).

Evidently, the idea of chyle flow which follows from this explanation of the action and the use of chyliferous vessels prevented Aselli from correctly finding the thoracic duct, which is the necessary step to make Galenic view's

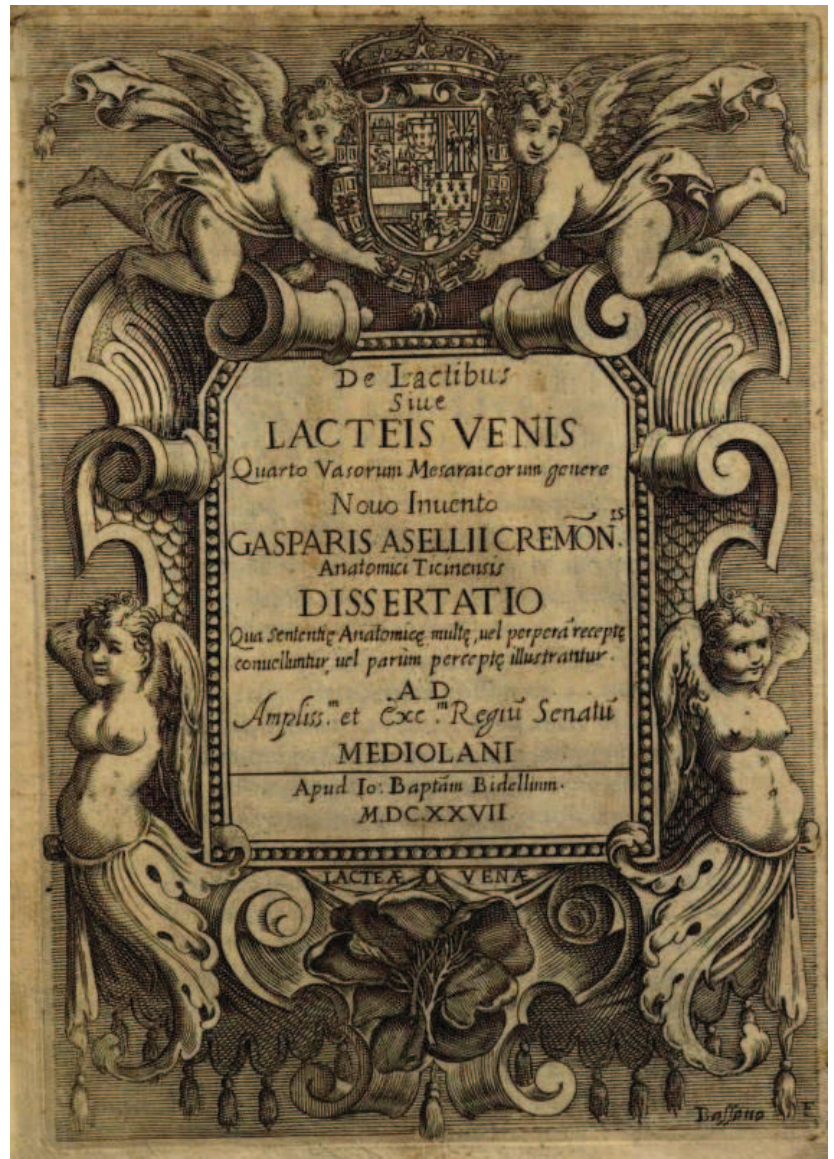

Figure 6 - Engraved title page, by Cesare Bassano. At the bottom: Anatomical illustration of the chyliferous vessels, labelled with the Latin name "Lacteae venae." From: De lactibus sive lacteis venis (1627).

refutation possible. In fact, it is necessary to show that the chyle cannot reach the liver.

Numerous historians of medicine agree to highlight the contraposition in Aselli's work between personal experiences by means of direct observations and dissections and the provided theoretical explanations. In this regard, for example, Portal said that "L'Auteur se perd dans une théorie qui n'est appuyée sur aucun principe de physique" (Ibidem): Aselli would not have supported Galen's theory, if he had been aware of the existence of the thoracic duct, which was already observed by Eustachi in horses. "En adaptant la découverte de ce grand homme à la sienne," he wrote, "Asellius eût conduit le chyle dans la veine souclaviere gauche, \& non dans le foie" (Ibidem). Similarly, in $19^{\text {th }}$ century, Charles Daremberg said: "Encore une fois, voilà ce que produit la mauvaise physiologie ou la physiologie a priori, la physiologie non expérimentale. Le hasard fait trouver les chylifères, la théorie galénique fait qu'on les voit se terminer au foie" ${ }^{31}$. 


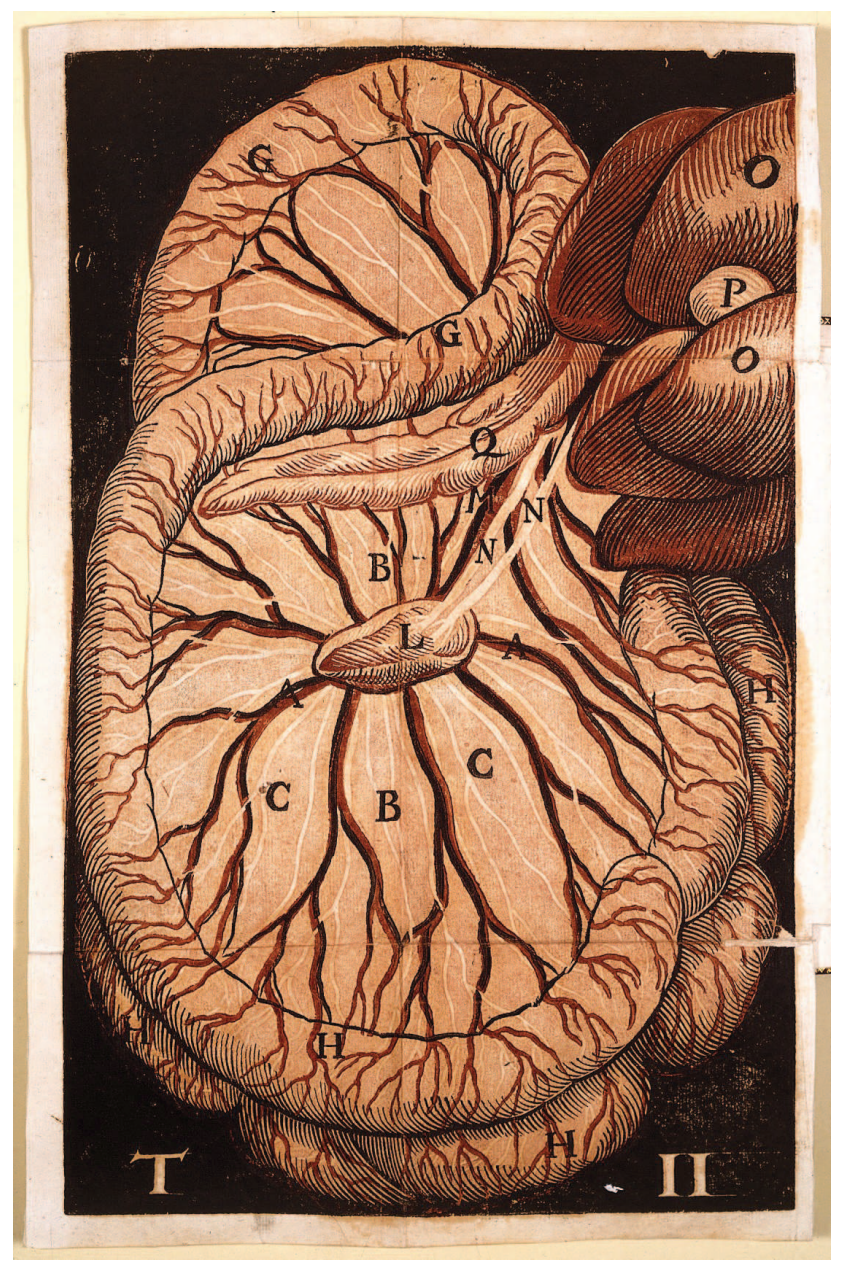

Figure 7 - One of the four chiaroscuro woodcuts. This plate, in particular, shows the relationship between the mesentery and the liver by means of the so-called "Aselli's pancreas." From: De lactibus sive lacteis venis (1627).

Jean Pecquet's Experimenta nova anatomica (Fig. $8)^{32}$, published in 1651 , can be viewed as a turning point in the studies on the lymphatic system, because it proves the existence of new anatomical structures involved, such as the 'receptaculum chyli' and the thoracic duct, and finally shows the chyle's correct path ${ }^{[\mathrm{ix}]}, 33,34$. This discovery, described in only about twenty pages by means of a single anatomical table, actually has important implications for the early modern medicine, as I will explain.

As he says at the beginning of his work, Pecquet does not dispute Aselli's discovery of milky veins, but he refuses his view on the chyle as it is still too dependent on Galen's hepatocentrism. Aselli has mistakenly taken for granted and not really verified that the milky veins gather in the liver's fissure. Numerous anatomists have debated on

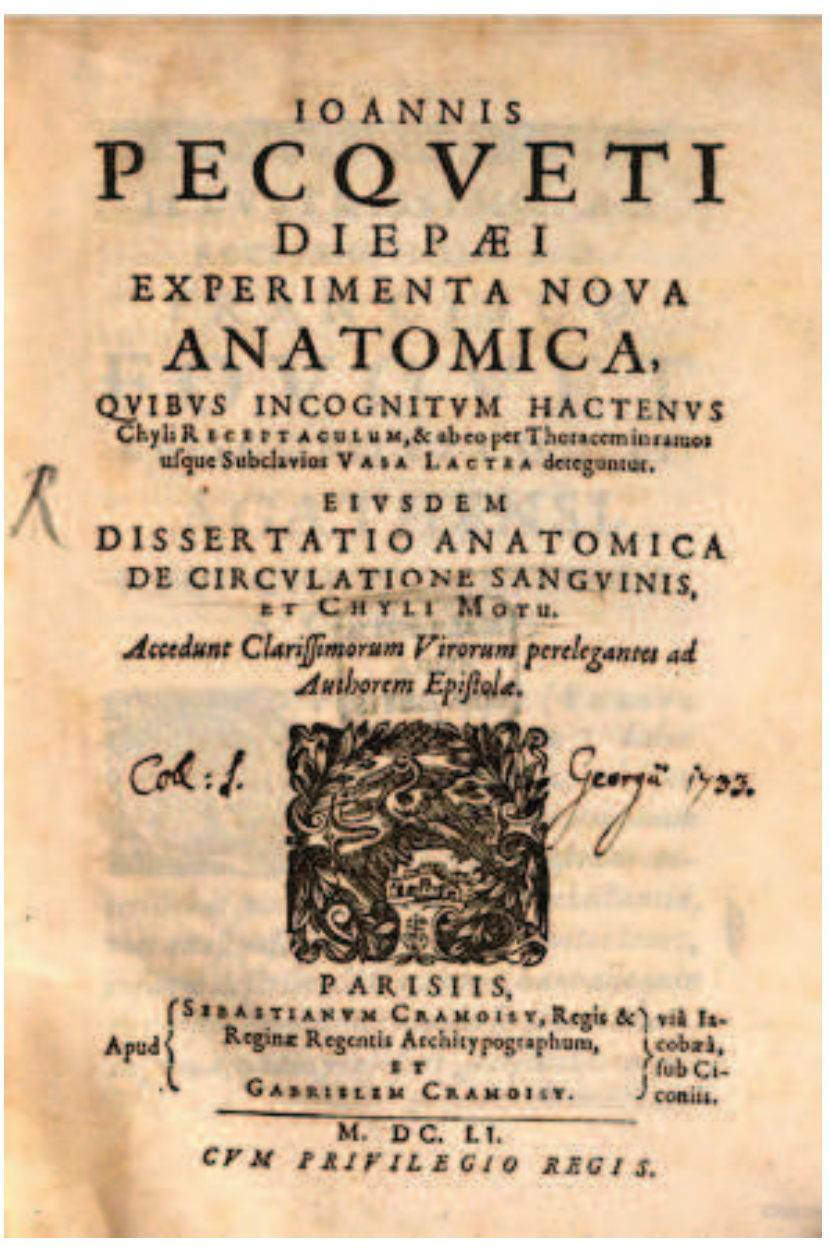

Figure 8 - Title page of Jean Pecquet's Experimenta nova anatomica (1651).

this issue (Walleus, Harvey, Conring, Bartholin, and Riolan too), arguing that a part of the milky vessels, scattered in the mesentery, meet in the pancreas, a part of them in the liver, a part of them in the vena cava, yet another part of them in the portal vein: Pecquet wants to demonstrate that the chyle is not collected by any of these parts.

Thus, a series of vivisections on a variety of animals have been performed for about three years, starting from 1647. These direct experiences on live animals allowed Pecquet to discover that, contrary to what was previously supposed, the chyle flows from the intestines into a sort of dilated sac, named the "receptaculum chyli." Then, it is led to the thoracic duct, a ladder-like structure through which it reaches the subclavian vein so as to finally meet the blood in the heart (Fig. 9). This implies that the liver is deprived of its traditional function because anatomical 
dissections demonstrate that it cannot receive the blood from the intestines. Then, what is its new role? Liver mainly serves as a means to "catalyse" digestion and filter the blood:

Praeter eam, qua fungitur, ut supra dictum est, vicem pistilli subjectas in infimo Ventre partes, Respirationis motu, percutientis, Hepar ingenti, quod accipit à Porta, Sanguinis profluvio calorem in ciborum elixationem Ventriculo subministrat; \& Sanguinem ipsum idoneo transcolat Parenchymate, utque Renes eundem sero repurgant, \& Lien aciditate Vendicat, sic Hepar admixtae Bilis expedit consortio (Pecquet, 1651, p. 86).

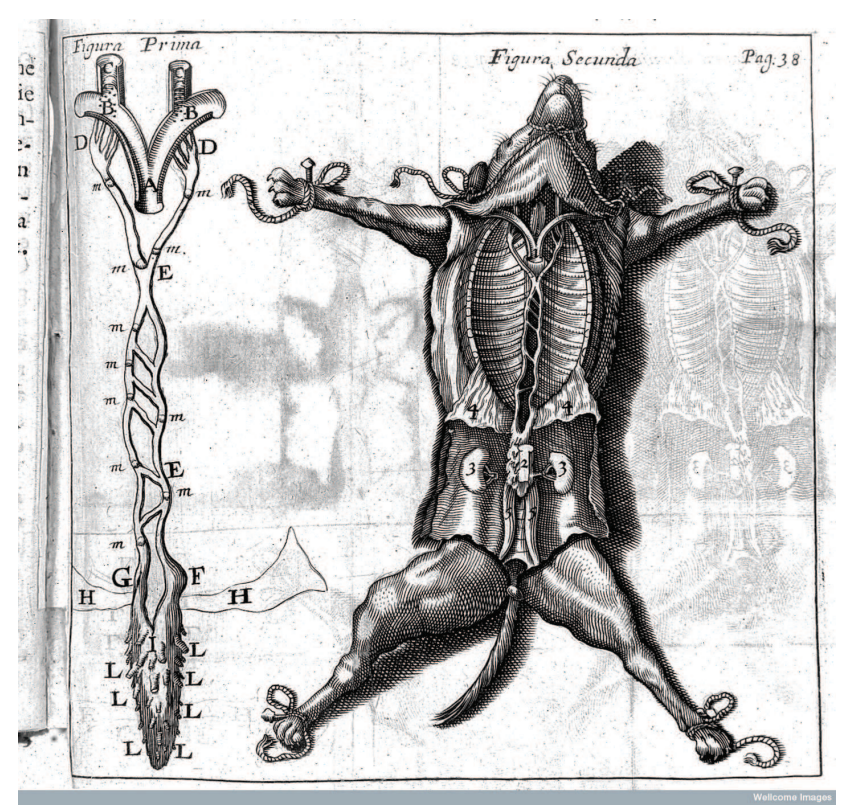

Figure 9 - Pecquet's anatomical illustration of a dissected dog. The thoracic duct is represented in two different ways: magnified (on the left) and in its natural proportions (on the right). From Pecquet (1651).

Moreover, in order to prove the relationship between chyle flow and blood circulation, Pecquet tries to produce

\section{Endnotes}

[i] For recent studies on the use of mercury in medicine and chemistry, see Hendriksen (2014).

[ii] The history of his experiments on lymphatics are outlined in the preface.

[iii] See, for example, all the contributions in the book section "Passioni di scienziato: I libri della biblioteca di Paolo Mascagni" (Vannozzi 1996).

[iv) The amount of secondary literature on Vesalius is huge. For an updated and annotated bibliography, see "Vesaliana," compiled by Maurits Biesbrouck and available from http://www.andreasvesalius.be. On Vesalius's anatomy, see Carlino (1994). See also Vons (2014).

[v] A second edition was published in 1555. Notes for a supposed third edition are analysed in Nutton (2012). not only new evidences in support of Harvey's theory, but also a valuable causal explanation of blood motion (and, consequently, of chyle), without any reference to Galenic faculties. He believes that air's elasticity, that he infers from 1640s experiments on Torricellian tube, can mechanistically explain blood and chyle motion ${ }^{[\mathrm{x}]}, 35,36$.

\section{Some clinical and methodological implications}

Pecquet's work has decisively influenced the modern conception of the body. We can draw some important anatomical, clinical, and methodological implications:

1) Through the demonstration of the thoracic duct, Pecquet launched one of the strongest attack on Galenism: since the blood does not pour out in the liver, the liver cannot exert the process of concoction, by transforming the chyle into blood. As a consequence, the liver lost its privileged role in the body.

2) Moreover, Pecquet proved that the chyle flow is circulatory. In 1653, in Vasa lymphatica, the Danish anatomist and physician Thomas Bartholin supported Pecquet's conclusions and showed that chyliferous vessels belong to a new vascular system, named "lymphatic system."

3) These discoveries gradually made it possible also to reveal new lymph borne diseases, as already suggested, albeit partially, by Aselli in the last chapter of his work (Aselli 1627, ch. 35) ${ }^{37}$.

4) Finally, Pecquet's three-year experiments on live animals pose the problem of evaluating the impact of vivisections on life sciences ${ }^{38}$. Moreover, the attempt to adapt physical researches to medicine shows the importance of collaborations between physicians and mathematicians in the foundation of a "mechanistic anatomy" and, more generally, in the development of late- $17^{\text {th }}$-century medicine.

[vi] Aselli's unpublished manuscripts are described in Ducceschi (1922). Aselli's four lessons on lacteals ("Lectiones de venis lacteis - Gasparis Aselii - de anno MDCXXV Ticini") are preserved in the Archive of the Civic Museum of Pavia.

[vii] On Fabricius's three-section structure, see Cunningham $(1985,1997)$ and Siraisi (2004)

[viii] The description of Aselli's discovery is outlined in Aselli (1627, ch. 9). A partial English translation of this passage is provided by Pomata (2005).

[ix) On Pecquet, see Bertonoli Meli (2011) and Guerrini (2015).

[x] Part of these experiments are reported and discussed in the dedicated section "Experimenta physico-mathematica de vacuo." Unfortunately, due to space limitation, a full account of Pecquet's 
arguments is omitted here. More details in Webster (1965) and Bertoloni Meli (2008)

\section{References}

1) Chickly B. Who Discovered the Lymphatic System?. Limphology. 1997; 30:186-193.

2) Ribatti D, Crivellato E. The Embryonic Origins of Lymphatic Vessels: An Historical Review. British Journal of Haematology. 2010; 149(5):669-674.

3) Loukas M, Bellary SS, Kuklinski M, Ferrauiola J, Yadav A, Shoja MM, Shaffer K, Tubbs RS. The Lymphatic System: A Historical Perspective. Clinical Anatomy. 2011; 24:807-816.

4) Suy R, Thomis S, Fourneau I. The Discovery of Lymphatic System in the Seventeenth Century. Part I: The Early History. Acta Chirurgica Belgica. 2016; 116(4):260-266

5) Allodi F. L'evoluzione del pensiero scientifico nelle opere di Paolo Mascagni. Rivista di Storia delle Scienze mediche e naturali. $1955 ; 47: 1-31$

6) Vannozzi F, editor. La scienza illuminata: Paolo Mascagn nel suo tempo (1755-1815). Siena: Nuova immagine; 1996.

7) Vannozzi F, editor. L'eredità intellettuale di Paolo Mascagni. Siena: Accademia delle Scienze di Siena detta de' Fisiocritici; 2015. Available from: http://www.fisiocritici.it/images/pdf/Leredita \%20intellettuale $\% 20$ di $\% 20$ Paolo $\% 20$ Mascagni.pdf

8) Mascagni P. Vasorum lymphaticorum corporis humani historia et ichnographia. Siena: Ex typographia Pazzini Carli; 1787.

9) Hendriksen MMA. Anatomical Mercury: Changing Understandings of Quicksilver, Blood, and the Lymphatic System, 1650-1800. Journal of the History of Medicine and Allied Sciences. $2014 ; 70(4): 516-48$.

10) Mascagni P. Prodrome d'un ouvrage sur le système des vaisseaux lymphatiques. A Sienne: Chez Vincent Pazzini Carli \& Fils; 1784.

11) Singer CJ. The Discovery of the Circulation of the Blood. London: G. Bell \& Sons; 1922.

12) Galen. On the Usefulness of the Parts of the Body, Vol. 1-2, translated by M.T. May. Ithaca, New York: Cornell University Press; 1968. p. 204

13) Carlino A. La fabbrica del corpo: libri e dissezione nel Rinascimento. Torino: Einaudi; 1994.

14) Vons J, editor. La Fabrique de Vésale. La mémoire d'un livre. Actes des journées d'étude des 21 et 22 novembre 2014. Paris: Bibliothèque Interuniversitaire de Santé; 2016. Available from http:// www.biusante.parisdescartes.fr/histoire/vesale/

15) Vesalius A. Tabulae anatomicae sex. Venetiis: sumptibus Ioannis Stephani Calcarensis, 1538.

16) Singer C. A Prelude to Modern Science: Being a Discussion of the History, Sources and Circumstances of the 'Tabulae anatomicae sex' of Vesalius. Cambridge: Cambridge University Press; 1946.

17) Vesalius A. De humani corporis fabrica libri septem. Basileae: [ex officina Ioannis Oporini]; 1543.

18) Nutton V. Vesalius Revised. His Annotations to the 1555 Fabrica. Medical History. 2012; 56(4):415-443.
19) Vesalius A. On the Fabric of the Human Body. Book V: The Organs of Nutrition and Generation, translated by William Frank Richardson. Novato-California: Norman Publishing; 2007. p. 111-2.

20) Colombo R. De re anatomica libri XV. Venetiis: ex typographia Nicolai Beuilacquae; 1559.

21) Colombo R. De re anatomica libri XV. Anatomia, edited by G. Baldo. Paris: Les Belles Lettres; 2014 (Italian translation).

22) Premuda L. Aselli, Gaspare. In: Dizionario Biografico degli Italiani. Rome: Istituto Enciclopedia Italiana; 1962. Vol. 4, ad vocem. Available from: http://www.treccani.it/enciclopedia/gaspareaselli_(Dizionario-Biografico)/.

23) Aselli G. De lactibus sive lacteis venis. Mediolani: apud Io. Baptistam Bidellium; 1627.

24) Ducceschi V. I manoscritti di Gaspare Aselli. Archivio di storia della scienza. 1922; 3:125-134.

25) Ekholm KJ. Fabricius's and Harvey's Representations of Animal Generation. Annals of Science. 2010; 67(3):329-352, esp. 350-352.

26) Cunningham A. Fabricius and the "Aristotle Project" in Anatomical Teaching and Research at Padua. In: Wear A., French R. Lonie I.M., editors. The Medical Renaissance of the Sixteenth Century. Cambridge: Cambridge University Press; 1985. p. 195-222.

27) Cunningham A. The Anatomical Renaissance: The Resurrection of the Anatomical Projects of the Ancients. Aldershot: Scolar Press; 1997. Ch. 6.

28) Siraisi N. Historia, actio, utilitas: Fabrici e le scienze della vita nel Cinquecento. In: Rippa Bonati M., Pardo-Tomás J., editors. Il teatro dei corpi. Le pitture colorate d'anatomia di Girolamo Fabrici d'Acquapendente. Guida all'esposizione: Venezia, Sale monumentali della Biblioteca nazionale Marciana (Libreria Sansoviniana), 17 dicembre 2004-8 maggio 2005. Milano: Mediamed; 2004. p. 63-73.

29) Pomata G. Praxis Historialis: The Uses of Historia in Early Modern Medicine. In: Pomata G., Siraisi N., editors. Historia: Empiricism and Erudition in Early Modern Europe. Cambridge, MA: MIT University Press; 2005. p. 105-146, esp. 118-9.

30) Portal A. Histoire de l'anatomie et de la chirurgie. Paris: Chez P. Fr. Didot le jeune, Quai des Augustins; 1770. p. 464.

31) Daremberg C. Histoire des sciences médicales. Paris: J.-B. Baillière; 1870. p. 621, n. 1 .

32) Pecquet J. Experimenta nova anatomica. Paris: S. et G. Cramoisy; 1651.

33) Bertoloni Meli D. Mechanism, Experiment, Disease. Marcello Malpighi and Seventeenth-Century Anatomy. Baltimore: The Johns Hopkins University Press; 2011. p. 32-40, esp. 37-40.

34) Guerrini A. The Courtiers' Anatomists. Animals and Humans in Louis XIV's Paris. Chicago-London: The University of Chicago Press; 2015. p. 76-80.

35) Webster C. The Discovery of Boyle's Law, and the Concept of the Elasticity of Air in Seventeenth Century. Archive for the History of Exact Sciences. 1965; 2(6):441-502. 
L Tonetti - The discovery of lymphatic system as a turning point in medical knowledge: Aselli, Pecquet and the end of hepatocentrism

36) Bertoloni Meli D. The Collaboration between Anatomists and Mathematicians in the mid-Seventeenth Century with a Study of Images as Experiments and Galileo's Role in Steno's Myology. Early Science and Medicine. 2008; 13:665-709, esp. 670-7.
37) Cosmacini G., La vita nelle mani. Storia della chirurgia. Roma-Bari: Laterza; 2003. p. 149-157.

38) Bertoloni Meli D, Guerrini A, editors. Special Issue on Vivisection. Journal of the History of Biology. 2013; 46(2):167-313. 